\title{
FLUIDS IN THE MANAGEMENT OF SEPSIS IN CHILDREN: A REVIEW OF GUIDELINES IN THE AFTERMATH OF THE FEAST TRIAL
}

Juan Emmanuel Dewez, ${ }^{1}$ Ruud Nijman, ${ }^{2,3}$ Shunmay Yeung ${ }^{1,3}$

1. London School of Hygiene and Tropical Medicine, London, United Kingdom

2. Imperial College of Science, Technology and Medicine, Section of Paediatrics, London, United Kingdom.

3. Department of Paediatrics, St Mary's hospital-Imperial College NHS Healthcare Trust

A recent editorial discusses how the FEAST trial, ${ }^{1}$ the only phase III randomised controlled trial assessing fluid bolus therapy (FBT) in severely ill African children, had little impact on guidelines despite the increased mortality risk in children receiving FBT. The editorial mentions the 2013 World Health Organisation (WHO) guideline which partially considers the FEAST trial results, and the 2014 American College of Critical Care Medicine guideline which does not.

We reviewed paediatric sepsis guidelines from the USA, the Surviving Sepsis Campaign (SSC), and from European countries to explore the impact of the FEAST trial on guidelines. We searched Medline, Embase, SIGN, websites of paediatric associations, and contacted paediatricians from each country.

Thirteen guidelines were identified (Table and supplementary file). All recommended immediate administration of fluids in septic children, with 10/13 guidelines recommending a first bolus of 20 $\mathrm{ml} / \mathrm{kg}$. Ten guidelines were published after the FEAST trial. Of these, 4/10 guidelines mentioned the trial, but only one (the American Heart Association-Pediatric Advanced Life Support guideline) recommended cautious FBT if access to critical care was limited; the three other guidelines concluded that the FEAST trial results did not apply to their populations because of a good access to critical care. Two guidelines recommended cautious FBT for other reasons (National Institute for Health and Care Excellence -NICE- and WHO guidelines).

These findings show the difficulty for evidence to be considered in the development of recommendations, particularly when it challenges current practice. Most guidelines base their recommendations on low-level evidence, which makes the omission of one of the few high-quality studies, conducted in low-resource settings, the more noticeable.

The Fluids In Shock trial ${ }^{2}$ explored the feasibility of conducting a similar trial in the UK, but concluded that such a trial would not be possible, because of the low incidence of sepsis and low adherence of staff to the trial protocol. However, despite these findings and given that the evidence on which guidelines in high-income countries are based is limited, ${ }^{3}$ there remains a need of well conducted trials in other high-income settings to address the unresolved issue of FBT in paediatric sepsis.

Competing Interest: None declared.

Funding: This project has received funding from the European Union's Horizon 2020 research and innovation programme under Grant Agreement No. 668303.

\section{References}

1. Maitland K, Kiguli S, Opoka RO, Engoru C, Olupot-Olupot P, Akech SO, et al. Mortality after fluid bolus in African children with severe infection. The New England journal of medicine. 2011 Jun 30;364(26):2483-95

2. Inwald D, Canter RR, Woolfall K, O'Hara CB, Mouncey PR, Zenasni Z, et al. Restricted fluid bolus versus current practice in children with septic shock: the FiSh feasibility study and pilot RCT. Health technology assessment (Winchester, England). 2018 Sep;22(51):1-106 
3. Opiyo N, Molyneux E, Sinclair D, Garner P, English M. Immediate fluid management of children with severe febrile illness and signs of impaired circulation in low-income settings: a contextualised systematic review. BMJ open. 2014 Apr 30;4(4):e004934

Table. Recommendations for fluid bolus therapy (FBT) in paediatric sepsis

\begin{tabular}{|c|c|c|c|c|c|}
\hline $\begin{array}{c}\text { Time of } \\
\text { publication } \\
\text { (after/before } \\
\text { FEAST trial) }\end{array}$ & $\begin{array}{c}\text { Institution, country or } \\
\text { international organization, and } \\
\text { year of publication* }\end{array}$ & $\begin{array}{c}\text { Does } \\
\text { guideline } \\
\text { recommend } \\
\text { immediate } \\
\text { FBT? }\end{array}$ & $\begin{array}{l}\text { Minimum } \\
\text { volume of } \\
\text { FBT }\end{array}$ & $\begin{array}{l}\text { Does } \\
\text { guideline } \\
\text { discuss } \\
\text { FEAST trial } \\
\text { results? }\end{array}$ & $\begin{array}{l}\text { Does guideline consider } \\
\text { restrictive fluids? }\end{array}$ \\
\hline \multirow[t]{10}{*}{ After } & $\begin{array}{l}\text { Surviving Sepsis Campaign } 2012 \\
\text { and } 2017^{* *}\end{array}$ & Yes & $20 \mathrm{ml} / \mathrm{kg}$ & Yes & No \\
\hline & SFR Paediatrics, Denmark, 2016 & Yes & $20 \mathrm{ml} / \mathrm{kg}$ & No & No \\
\hline & NICE, United Kingdom, 2016 & Yes & $20 \mathrm{ml} / \mathrm{kg}$ & Yes & $\begin{array}{c}\text { In cardiac or kidney } \\
\text { diseases }\end{array}$ \\
\hline & AWMF, Germany, 2015 & Yes & $20 \mathrm{ml} / \mathrm{kg}$ & Yes & No \\
\hline & AHA-PALS, USA, 2015 & Yes & $20 \mathrm{ml} / \mathrm{kg}$ & Yes & $\begin{array}{c}\text { In children without } \\
\text { access to intensive care }\end{array}$ \\
\hline & $\begin{array}{l}\text { National Medicines Institute, } \\
\text { Poland, } 2014\end{array}$ & Yes & $\begin{array}{c}\text { Not } \\
\text { specified }\end{array}$ & No & No \\
\hline & NCEC, Ireland, 2014 & Yes & $20 \mathrm{ml} / \mathrm{kg}$ & No & No \\
\hline & WHO, 2013 & Yes & $20 \mathrm{ml} / \mathrm{kg}$ & No & $\begin{array}{l}\text { In malnourished children, } \\
\text { malaria, and anaemia }\end{array}$ \\
\hline & $\begin{array}{l}\text { Norwegian Children's } \\
\text { Association, Norway, after } 2013\end{array}$ & Yes & $20 \mathrm{ml} / \mathrm{kg}$ & No & No \\
\hline & SIP-SCIP, Portugal, after 2012 & Yes & $10 \mathrm{ml} / \mathrm{kg}$ & No & No \\
\hline \multirow[t]{3}{*}{ Before } & $\begin{array}{l}\text { Mater Dei Hospital, Malta, } \\
2010\end{array}$ & Yes & $20 \mathrm{ml} / \mathrm{kg}$ & $\begin{array}{c}\text { Not } \\
\text { applicable }\end{array}$ & No \\
\hline & SECIP-SEUP, Spain, after 2009 & Yes & $20 \mathrm{ml} / \mathrm{kg}$ & $\begin{array}{c}\text { Not } \\
\text { applicable }\end{array}$ & No \\
\hline & SFAR/SRLF, France, 2006 & Yes & $\begin{array}{c}\text { Not } \\
\text { specified }\end{array}$ & $\begin{array}{c}\text { Not } \\
\text { applicable }\end{array}$ & No \\
\hline
\end{tabular}

*Full title of guidelines and publishing institutions in Supplementary file

**We are aware that the SSC has new paediatric guidelines that are not yet published. 